\title{
Sistem Pendukung Keputusan Mencari Pelaksana Program Kerja Terbaik Menggunakan Metode MOORA
}

\author{
Jaka Tirta Samudra*, Puji Sari Ramadhan** \\ * Magister Ilmu Komputer, Universitas Potensi Utama \\ ** Sistem Informasi, STMIK Triguna Dharma
}

\begin{tabular}{|c|c|}
\hline Article Info & ABSTRACT \\
\hline Article history: & Untuk meningkatkan mutu dan kuantitas dari instansi P2KB\&P3A Kabupaten \\
\hline Received Jan $13^{\text {th }}, 2022$ & Deli Serdang dirancang dalam struktur program kerja yang dilaksanakan untuk \\
\hline Revised Feb $20^{\text {th }}, 2022$ & desa binaan agar terlaksana kemakmuran desa serta kepada masyarakat. Dalam \\
\hline Accepted Feb 24 $4^{\text {th }}, 2022$ & $\begin{array}{l}\text { hal ini untuk sebuah instansi yang berlangsung kaitannya dengan pemerintah } \\
\text { dirancang dari masalah yang terkait untuk menentukan kelayakan pada } \\
\text { program kerja yang dibuat selama } 1 \text { tahun guna mencari program kerja yang }\end{array}$ \\
\hline $\begin{array}{l}\text { Keyword: } \\
\text { MOORA } \\
\text { P2KB\&P3A } \\
\text { Program Kerja Terbaik } \\
\text { Sistem Pendukung Keputusan } \\
\text { Website }\end{array}$ & $\begin{array}{l}\text { terbaik dimana untuk dipertahankan, diubah program kerja struktur } \\
\text { rancangannya atau juga di hapuskan karena tidak memiliki eksistensi yang } \\
\text { mendukung bagi kualitas dan kuantitas untuk desa serta masyarakatnya, maka } \\
\text { akan dirancang suatu sistem pendukung keputusan yang berbasis aplikasi } \\
\text { website yang mengapdosi penggunaan metode multi-objective optimization on } \\
\text { the basis of ratio analysis (MOORA) pada instansi P2KB\&P3A. Dari hasil } \\
\text { perhitungan, instansi dalam penyeleksi dan menentukan dari hasil program } \\
\text { kerja yang dibuat untuk } 1 \text { tahun sebagai aspek kinerjanya. Dengan metode } \\
\text { MOORA dapat membantu serta mempermudah dalam analisa dan menentukan } \\
\text { setiap program kerja dari } 22 \text { Kecamatan Se-Deli Serdang di instansi } \\
\text { P2KB\&P3A Kabupaten Deli Serdang tersebut. }\end{array}$ \\
\hline
\end{tabular}

Copyright $\odot 2022$ STMIK Triguna Dharma. All rights reserved.

\author{
Corresponding Author: *First Author \\ Nama : Jaka Tirta Samudra \\ Program Studi : Ilmu Komputer \\ Universitas Potensi Utama \\ Email : jakatirta135@gmail.com
}

\section{PENDAHULUAN}

Kabupaten Deli Serdang yang merupakan kabupaten yang memiliki cangkupan yang luas sekitar 2.808,91 $\mathrm{km}^{2}$ merupakan salah satu keluasasan didaerahnya dari setiap kabupaten yang ada di Indonesia. Dalam pemerintahannya memiliki salah satu tanggapan yang secara langsung dari bupati yang ditanggungin oleh sekretaris sendiri [1].

Terlepas dari luas daerah kabupaten Deli Serdang dari jumlah statistik yang telah tercatat yang terupdate dari badan pusat statistik kabuapten Deli Serdang dengan last update terakhir ditanggal 20 april 2018 sejumlah 2.497.72 penduduk jiwa bahkan sudah tercatat sejak tahun lalu. Dari sejak tahun 1 juli 1946 sebagai penetapan sah pada kabupaten Deli Serdang yang berdiri dari kabupaten di Medan maka dari itu dari program kerja yang terus di laksanakan dan juga sebagai wadah komitmen pemerintah untuk meningkatkan kemajuan desa sebasar 2,19\% dengan memiliki target sebesar 4\% di tahun 2020-2025 mendatang.

Pada program kerja yang dilaksanakan pada kontribusi dari 22 desa yang pada umumnya, akan tetapi dari setiap program kerja yang dilaksanakan masih banyak kelemahan yang terjadi pada setiap susunan program kerjanya. Setiap program kerja tidak terdapat kesempatan untuk memicu lebih detail setiap menjadwalkan program kerja pelaksana masih secara manual pada penetapan program kerja yang baik dari setiap desa [2].

Setiap penetapannya yang sudah ada pada subbidang yang menjadi tolak ukur perkembangan desa hanyala sebatas pelaksana bukan menjadi angket mendorong kemajuan yang menjadi impian pada perangkat desa. Terhadap pelaksana terus dicoba dalam menyeleksi setiap divisi subbidang penyelenggara dari sub 
keluarga berencana, perlindungan anak, pengendalian penduduk, pemberdayaan perempuan, keluarga sejahtera serta secretariat yang memiliki progras dalam 1 tahun yang wajib dilaksanakan dalam penyelesaian anggaran dana dari APBN negara [3].

Dengan fleksibel serta secara nyata sistem akan menetukan bentuk dari masalah yang ada pada program kerja dalam pemilihan program kinerja yang terbaik dengan kuantitas memadai. Dengan memanfaatkan perhitungan dari metode MOORA (Multi-Objective Optimization On The Basis Of Ratio Analysis) menggunakan sistem perangkat lunak berbasis website. Penerapan yang dilakukan mengambil dari nilai penting sebagai subjek yang orientitas untuk dijadikan sampel perhitungan yang lebih dari 2 nilai dalam mendapatkan hasil dari jumlah yang terbaik dari program pelaksana.

Proses mengoptimalkan dua atribut atau lebih yang saling bertentangan dengan batas tertentu dan penentuan bobot setiap atributnya, lalu proses perangkingan untuk menyeleksi alternatif terbaik sehingga dapat menyelesaikan masalah dalam pengambilan keputusan yang rumit dalam penerimaan Bantuan Stimulan Perumahan Swadaya (BSPS) merupakan penerapan metode MOORA [4].

Sistem Pendukung Keputusan tidak dimaksudkan untuk mengotomatiskan pengambilan keputusan, tetapi memberikan perangkat interaktif yang memungkinkan pengambil keputusan untuk melakukan berbagai analisis menggunakan model-model yang tersedia [5].

Dalam penerapannya pada Decision support system (DSS) atau dengan istilah sistem pendukung keputusan (SPK), diangkat untuk memilih data pada kriteria pelaksana program kerja selama 1 tahun. Perhitungan yang digunakan dalam algoritma itu Rank Order Centroid (ROC) digunakan dalam mengangkat setiap nilai bobot pada setiap kriteria yang dilandaskan pada tingkatan kepentingan atau prioritas pada pemberian setiap kriteria [6]. Dimana dalam ungkapan kriteri ke 1 itu lebih penting dari kriteria ke 2 dan juga kriteria ke 2 lebih penting pada kriteria ke 3 begitu dalam tahapan seterusnya yang ada pada saat diberikan pada nilai angka tertinggi [7].

\section{METODE PENELITIAN}

Dalam menerapkan metode MOORA sebagai penelitian ini disebabkan dalam sistem multi-objektif dimana dalam pemecahannya mengoptimalkan dua atau lebih dari setiap attribute yang saling bertentangan secara bersamaan [8]. Dalam pengumpulan data di pakai pada metode untuk memecahkan masalah dalam membantunya yaitu pakai metode Observasi, Wawancara (interview), serta Kuesioner [9].

Dikarenakan dalam penelitian ini menggunakan dari konsep pada pendekatan eksperimental maka dibawah ini adalah penggunakan metode penelitian, sesuai dengan gambar 1 sebagai berikut :

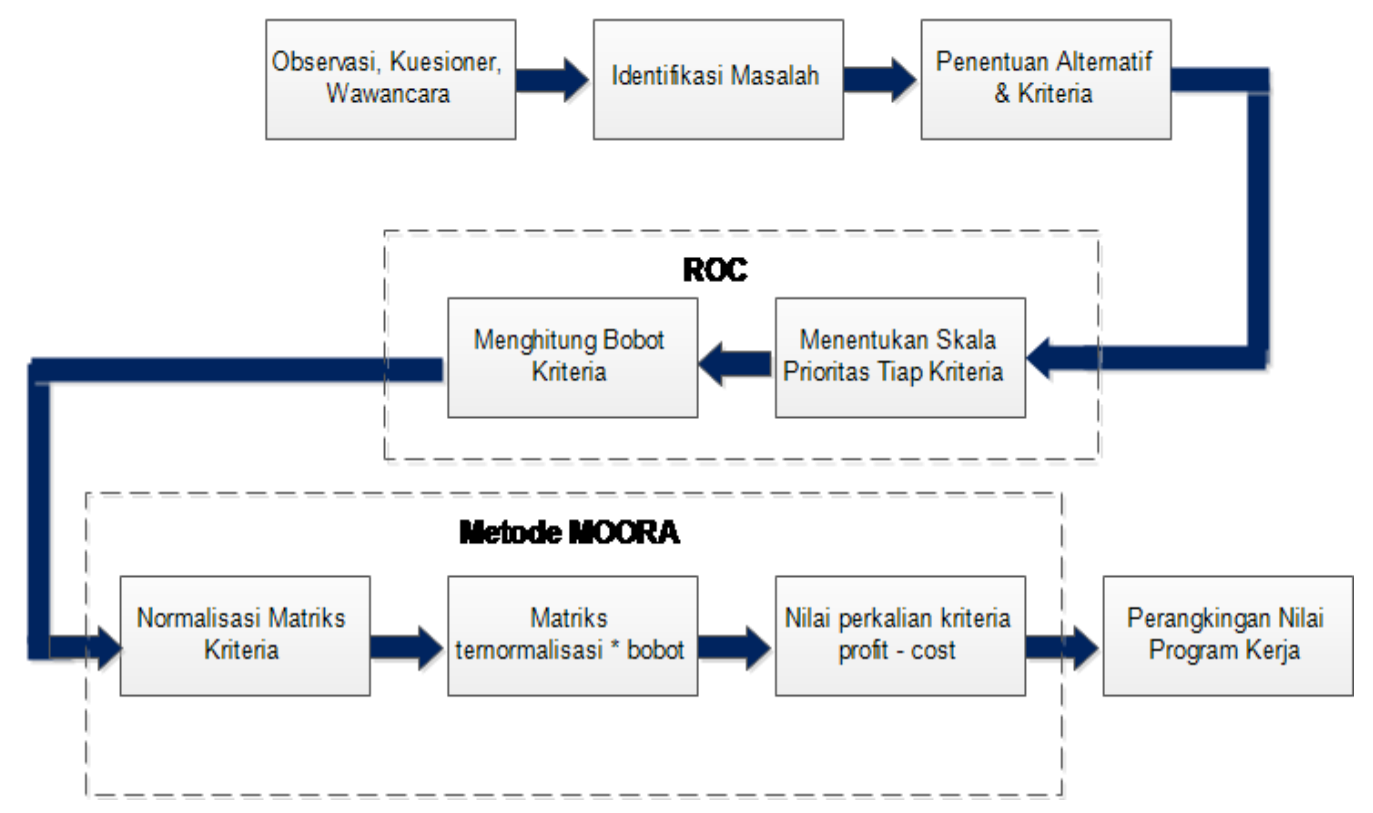

Gambar 1. Metode Penelitian

Berikut ini adalah fase dalam melakukan pada penelitian yang diangkat sebagai pada gambar 2 mengikuti dari waterfall menurut Pressman [10] yaitu: 


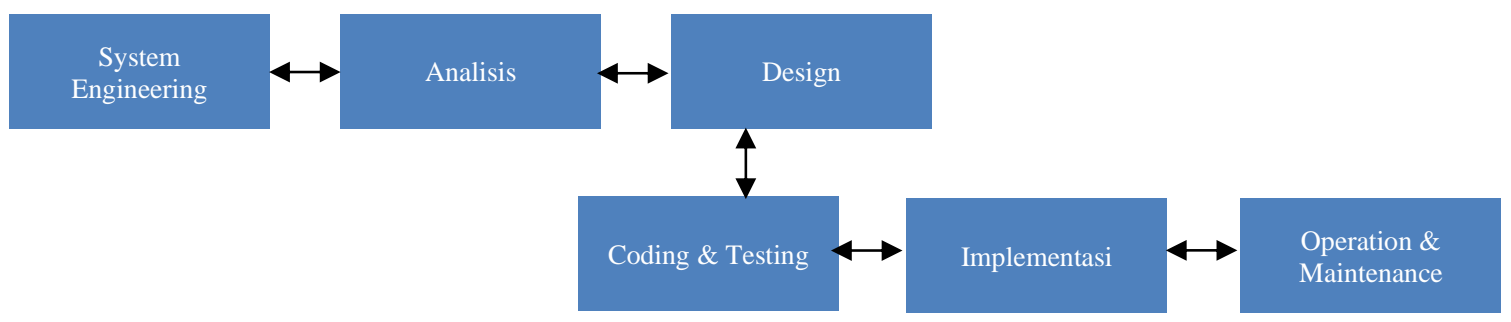

Gambar 2. Waterfall ini.

Berikut tabel 1 merupakan attribut kriteria sebanyak 12 dengan keterangan bobot, dapat dilihat dibawah

Tabel 1. Nilai Bobot Kriteria

\begin{tabular}{cccc}
\hline No & Nama Kriteria & Bobot & Jenis \\
\hline 1 & Jumlah Ikut Serta Desa Binaan & 0.1 & Benefit \\
2 & Lama Kegiatan & 0.06 & Benefit \\
3 & Anggaran Biaya & 0.2 & Benefit \\
4 & Insfrastruktur Program Kerja & 0.05 & Cost \\
5 & Jumlah Ikut Serta Pegawai & 0.025 & Cost \\
6 & Jumlah Peserta Ikut & 0.015 & Benefit \\
7 & Jumlah Kegiatan Kec. 1 Bulan & 0.1 & Benefit \\
8 & Sisa Anggaran Biaya & 0.15 & Cost \\
9 & Target Pencapaian Kinerja 1 Bulan & 0.05 & Benefit \\
10 & Penerimaan Hasil Pelaksana & 0.1 & Benefit \\
11 & Target Kegiatan & 0.05 & Benefit \\
12 & Indikatif & 0.1 & Benefit \\
\cline { 1 - 2 } & Total & 1 & \\
\hline
\end{tabular}

Berikut tabel 2 merupakan penilaian kriteria pada setiap nilai bobot yang ada pada alternatif, dapat dilihat dibawah ini.

Tabel 2. Penilaian Alternatif Pada Kriteria

\begin{tabular}{cccccccccccccc}
\hline No & Alternatif & K1 & K2 & K3 & K4 & K5 & K6 & K7 & K8 & K9 & K19 & K11 & K12 \\
\hline 1 & A1 & 1 & 1 & 1 & 3 & 1 & 3 & 2 & 4 & 3 & 3 & 4 & 1 \\
2 & A2 & 1 & 2 & 1 & 3 & 3 & 4 & 3 & 4 & 4 & 4 & 3 & 1 \\
$\ldots$ & $\ldots$ & $\ldots$ & $\ldots$ & $\ldots$ & $\ldots$ & $\ldots$ & $\ldots$ & $\ldots$ & $\ldots$ & $\ldots$ & $\ldots$ & $\ldots$ & $\ldots$ \\
59 & A59 & 1 & 1 & 2 & 3 & 2 & 1 & 4 & 4 & 2 & 4 & 4 & 1 \\
60 & A60 & 1 & 1 & 2 & 3 & 3 & 2 & 4 & 4 & 2 & 4 & 3 & 1 \\
61 & A61 & 4 & 2 & 2 & 3 & 2 & 2 & 4 & 4 & 4 & 4 & 4 & 1 \\
62 & A62 & 3 & 1 & 1 & 3 & 2 & 2 & 2 & 3 & 3 & 3 & 4 & 1 \\
\hline
\end{tabular}

Perhitungan Nilai Yi Pada Metode MOORA yang ada pada alternatif, sesuai dengan tabel 3 dibawah ini

Tabel 3. Nilai Yi Pada Metode MOORA

\begin{tabular}{|c|c|c|c|c|}
\hline No & Alternatif & $\begin{array}{c}\text { Maximum } \\
\mathrm{K} 1+\mathrm{K} 2+\mathrm{K} 3+\mathrm{K} 6+\mathrm{K} 7+\mathrm{K} 9+\mathrm{K} 10+\mathrm{K} 11+\mathrm{K} 12\end{array}$ & $\begin{array}{c}\text { Minimum } \\
\mathrm{K} 4+\mathrm{K} 5+\mathrm{K} 8\end{array}$ & $\begin{array}{c}\mathrm{Yi} \\
\text { Max-Min }\end{array}$ \\
\hline 1 & A1 & 0.06526 & 0.03039 & 0.03487 \\
\hline 2 & $\mathrm{~A} 2$ & 0.07913 & 0.03262 & 0.04651 \\
\hline$\ldots$ & $\ldots$ & $\ldots$ & $\ldots$ & $\ldots$ \\
\hline
\end{tabular}




\begin{tabular}{lllll}
\hline 60 & A60 & 0.08624 & 0.03262 & 0.05362 \\
61 & A61 & 0.11420 & 0.03150 & 0.08270 \\
62 & A62 & 0.07679 & 0.02574 & 0.05105 \\
\hline
\end{tabular}
ini.

Berikut ini hasil dari nilai yang sudah ditentukan dari metode MOORA, sesuai dengan tabel 4 dibawah

Tabel 4. Perangkingan

\begin{tabular}{cclcc}
\hline No & Alternatif & \multicolumn{1}{c}{ Program Kerja } & Hasil & Rangking \\
\hline 1 & A14 & $\begin{array}{l}\text { Rapat-rapat koordinasi dan konsultasi ke luar dan dalam } \\
\text { daerah }\end{array}$ & 0.11121 & 1 \\
2 & A5 & Penyediaan Jasa Kebersihan Kantor & 0.11078 & 2 \\
$\ldots$ & $\ldots$ & $\ldots$ & 0.03487 & 60 \\
60 & A1 & Penyediaan Jasa Surat Menyurat & 0.03482 & 61 \\
61 & A30 & Pemeliharaan Rutin / Berkala Peralatan Gedung Kantor & 0.02954 & 62 \\
62 & A43 & Pelatihan Konvensi Hak Anak (KHA) \\
\hline
\end{tabular}

Berdasarkan dari hasil perangkingan yang didapatkan dalam penerapan metode Multi-Objective Optimization On The Basis Of Ratio Analysis (MOORA) telah ditentukan pada alternatif A14 dengan program kerja Rapat-rapat Koordinasi dan Konsultasi Ke Luar dan Dalam Daerah mendapatkan nilai tertinggi. Serta pada perangkingan terakhir didapatkan pada alternatif A43 dengan program kerja Pelatihan Konvensi Hak anak (KHA) dengan nilai terendah.

\section{ANALISA DAN HASIL}

Dalam perancangan dari pembuatan menu setiap aplikasi sistem pendukung keputusan untuk menentukan pelaksana program kerja terbaik dari kantor dinas Pengendalian Penduduk, KB \& Pemberdayaan Perempuan, Perlindungan Anak di Kabupaten Deli Serdang dengan menerapkan apa sistem berbasis website.

Konsep dari gambaran sistem aplikasi berbasis website sebagai berikut, sesuai dengan gambar 3 berikut.

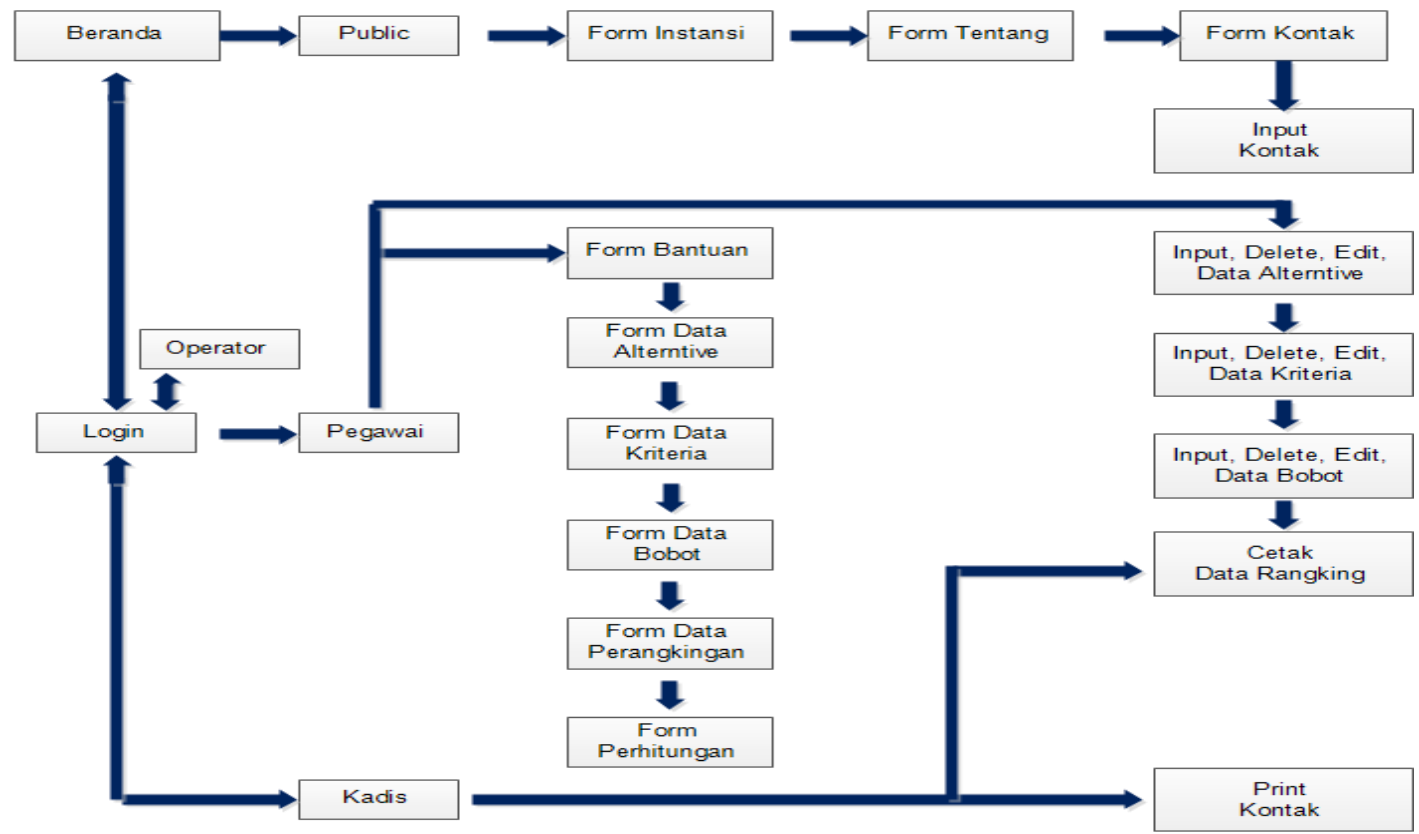

Gambar 3. Perancangan Aplikasi Website

Dalam konsepnya yang telah digambarkan pada alur dari pada pemodelan sistem pada aplikasi yang dibangun menggunakan website. Konsep dari pada use case sistem aplikasi yang dibangun sesuai dengan gambar 4 berikut : 


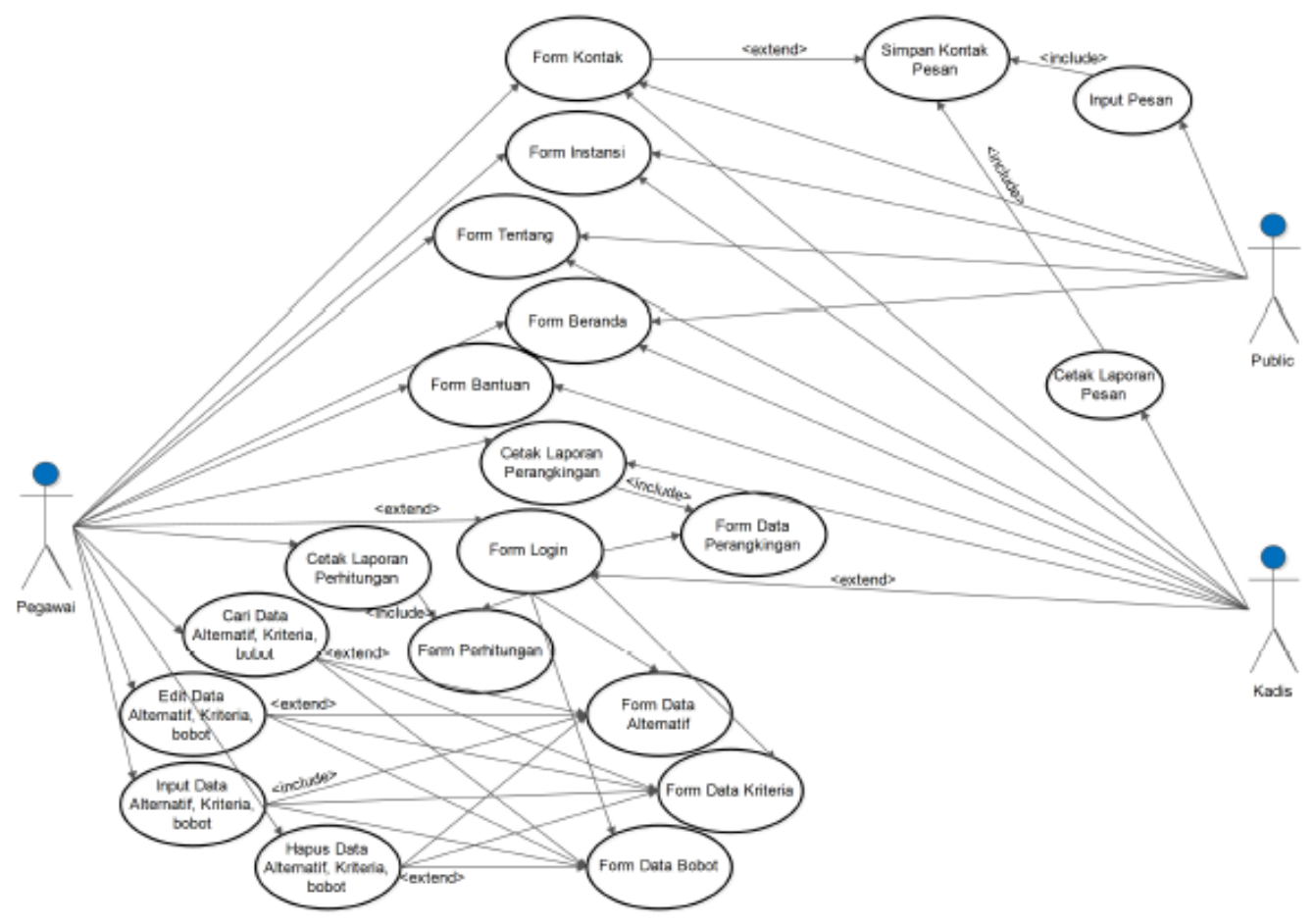

Gambar 4. Pemodelan Sistem Pada Use Case

\section{KESIMPULAN}

Pada kesimpulan ini bahawasanya untuk menentukan pelaksanaan program kerja dari instansi P2KB\&P3A dapat diterapkan pada metode MOORA yang menjadi data diambil sebanyak 62 data program kerja dari 22 kecamatan deli serdang. Dengan pelaksana program kerja Rapat-rapat Koordinasi dan Konsultasi Ke Luar dan Dalam Daerah mendapatkan nilai tertinggi serta pada perangkingan terakhit didapatkan pada program kerja Pelatihan Konvensi Hak anak (KHA) dengan nilai terendah. Maka dari itu bisa saja untuk data akurasi pendukung keputusan bisa menggunakan kepada metode lain untuk melakukan perbandingan data set yang ada atau melakukan pengelolaan kepada metode lainnya.

\section{UCAPAN TERIMA KASIH}

Terima kasih kepada Bapak Puji Sari Ramadhan, dan STMIK Triguna Dharma serta pihak-pihak yang mendukung penyelesaian artikel ilmiah ini.

\section{REFERENSI}

[1] K. Arifin, Warjio, "Implementasi Keputusan Bupati Deli Serdang Nomor 176 Tahun 2015 tentang Penetapan Operasional Mobil Layanan," J. Adm. Publik, vol. 6, no. 1, pp. 56-74, 2016.

[2] K. Haluana and W. Mustafa, "Peran Kecamatan dalam Pembangunan Infrastruktur Jalan di Kecamatan Beringin Kabupaten Deli Serdang," J. Ilmu Pemerintah. dan Sos. Polit. UMA, vol. 4, no. 1, pp. 11-22, 2016.

[3] D. Michael, "Pengelolaan Keuangan Desa Dalam Perspektif Hak Asasi Manusia: Studi Terhadap Pengelolaan Keuangan Desa Di Desa Sei Baharu, Kecamatan Hamparan Perak, Kabupaten Deli Serdang, Provinsi Sumatera Utara," J. HAM, vol. 8, no. 2, pp. 131-143, 2017.

[4] J. Hutagalung, and U. F. Sari, "InfoTekJar: Jurnal Nasional Informatika dan T. Jaringan, " Penerapan Metode KMeans dan MOORA Dalam Penerimaan Bantuan Stimulan Perumahan Swadaya ( BSPS ),” vol. 6, no.1, pp. 30-42, 2021.

[5] M. Ramadhan, D. Nofriansyah, and F. Rizky, "Sistem Pendukung Keputusan Pemberian Bantuan Program Keluarga Harapan (PKH) dengan Metode Elimination Et Choix Traduisant la Realite (ELECTRE) Studi Kasus Kecamatan Borbor," J. SAINTIKOM (Jurnal Sains Manaj. Inform. dan Komputer), vol. 18, no. 1, p. 17, 2019, doi: 10.53513/jis.v18i1.99.

[6] L. F. Israwan, "Penerapan Multi-Objective Optimization On The Basis Of Ratio (Moora) Dalam Penentuan Asisten Laboratorium," J. Ilm. Ilmu Komput., vol. 5, no. 1, pp. 19-23, 2019.

[7] R. T. Utami, D. Andreswari, and Y. Setiawan, "Implementasi Metode Simple Additive Weighting (SAW) Dengan Pembobotan Rank Order Centroid (ROC) Dalam Pengambilan Keputusan Untuk Seleksi Pengguna Jasa Leasing 
Mobil (Studi Kasus PT. Multindo Auto Finance Cabang Bengkulu),” J. Rekursif, vol. 4, no. 2, pp. 209-221, 2016.

[8] D. Nofriansyah and S. Defit, Multi Criteria Decision Making (MCDM) Pada Sistem Pendukung Keputusan, 1 st ed. Yogyakarta: DEEPUBLISH, 2017.

[9] P. Soepomo, "Sistem Pendukung Keputusan Dalam Penilaian Kinerja Pegawai Untuk Kenaikan Jabatan Pegawai Menggunakan Metode Gap Kompetensi (Studi Kasus Perusahaan Perkasa Jaya Compuretail)," J. Sarj. Tek. Inform., vol. 1, no. 2, pp. 574-583, 2013.

[10] C. Tristianto, "Penggunaan Metode Waterfall Untuk Pengembangan Sistem Monitoring Dan Evaluasi Pembangunan Pedesaan," Teknol. Inf. ESIT, vol. XII, no. 01, pp. 8-22, 2018.

\section{BIBLIOGRAFI PENULIS}

\begin{tabular}{|l|l|} 
Nama: Jaka Tirta Samudra, S.Kom. \\
Alumni STMIK Triguna Dharma Tahun 2020 yang saat ini sedang menempuh pendidikan \\
Magister Ilmu Komputer di Universitas Potensi Utama Medan.
\end{tabular}

